\title{
The Management Of Toxic and Hazardous Waste Materials In The Food Industry
}

\author{
Taufan Herry Setiawan ${ }^{1, *}$, Purwanto Purwanto ${ }^{1,2}$ \\ ${ }^{1}$ Master Program in Environmental Sciences, Postgraduate Program, University of Diponegoro, Semarang - Indonesia \\ ${ }^{2}$ Department of Chemical Engineering, Faculty of Engineering, University of Diponegoro, Semarang - Indonesia
}

\begin{abstract}
Activities of Industry can potentially be the pollutant and harm the environment if it is not managed properly and can be detrimental to the industries, people and the environment. One of them is the food industry that produces raw materials of products and waste from the production process in the form of hazardous and toxic materials waste. This research uses descriptive approach that aims to evaluate industrial activities that produce toxic materials and hazardous waste. The management and utilization of toxic and hazardous waste materials require the consent of the ministry of environment based on Regulation of Government number 101 of 2014. The method of utilization of toxic and hazardous waste materials that have been applied in other industries can be applied in the food industry. This utilization method is required for the management and utilization of toxic and hazardous waste materials in the food industry because the waste is not utilized or recycled, only stored in a temporary storage warehouse and later sent to the container
\end{abstract}

Keywords: toxic and hazardous waste materials; regulation 101; food industry.

\section{Introduction}

Development activities that are currently carried out are one effort to improve the quality of human life. Various development is prosecuted by managing and utilizing available resources for the purposes and interests of development, one of which is industrial activity.

The rapid development and growth of the industrial world are very beneficial for humans. On the other hand, it can also cause a considerable negative effect for it will produce waste either in solid, liquid, or gas that can decrease environmental quality. Development as an important thing should go in line with environmental development. There are three part of modern development philosophy : economics, social, and environment. Development recently absolutely requires environmentally friendly, such as low carbon, low negative impact, etc.

Waste is the residual material produced by a business and/or activity either on an industrial scale, household, agency, and others. To keep the stable environmental quality, the wastes must be processed and controlled. One of the ways is by managing and treating waste in accordance with their respective characteristics so the waste that will be discharged to the environment has fulfilled the requirements and correspond with the quality standard in the applicable laws and regulations.

Currently, waste issues have become a serious concern in various regions of Indonesia. This is shown by the increasing number of problems that explain how waste management and processing has not been a serious concern for most industries in Indonesia. Industrial development is not in line with the handling of waste because the procurement of waste management and processing facilities is still considered expensive and burdensome for some industry players.

The variety of this type of waste depends on activity of industry and other waste generators. Started by the use of raw materials, selection of production processes and so forth, all the processes will affect the character of the generated waste. Generally, the type of waste which is generated in the instant noodle industry is the same as other food industries, the difference is only in the characteristics that correspond to the raw materials used. The wastes include liquid waste, solid, and waste gas. To reduce the adverse effects of waste on the environment, it is necessary to manage the waste systematically after being produced.

Problems about waste management can have an impact on environmental pollution and may harm human beings, industry actors and the environment itself. The pollution process of industrial hazardous and toxic materials can occur directly or indirectly. The direct process is when pollutants have direct acute and poisonous effects that interfere with human health and adversely affect the environment, animals, and plants or disrupt the ecological balance of air, water, and soil. While the indirect process is when the pollutants have an indirect impact and delayed effect on humans and the

* Corresponding author: taufan herry@,yahoo.com 
environment and will only be felt after a certain period of time. In other hand, mismanagement of waste may cause carbon to blow out to atmosphere and make domino affect to other environmental problems.

According to the Law of the Indonesian Republic number 32 of 2009 on the Protection and Management of the Environment, toxic and hazardous waste materials are the remains of a business and/or activity containing hazardous and toxic materials. Whereas in Regulation of Government of the Indonesian Republic number 101 of 2014 concerning the Management of Toxic and hazardous wastes, it is explained that toxic and hazardous waste is the residue of a business and or activity in the form of substances, energy and/or other components due to its nature, concentration and/or quantity, either indirectly or directly, may pollute and or damage the environment, and or endanger the environment, health, and the survival of human beings and other living beings.

Toxic and hazardous waste that previously does not undergo a good management can have a very large and accumulative negative impact and the levels are increasing over time. Toxic and hazardous waste materials that are directly discharged into the environment can harm the environmental stability, human health, and other living things. According to the possibility of upcoming great risk, it is advised to minimize the waste of each industrial activities [3].

According Sulistyani (2007), the disposal of toxic and hazardous waste materials that contaminate groundwater and its surface will cause possible adverse effects on human health, the source of closed drinking water, community changes and the deaths of aquatic animals. There are several examples of the impact of illegally discharging waste into the environment such as the Minamata tragedy in Japan in the 1950s that made many people suffer from Congenital disease due to the Methyl-Mercury being wasted arbitrarily. Also the tragedy at Love Canal, the USA in the 1970s where there was a lot of toxic and hazardous waste material stockpiled with poor management (Priono, 2018a).

Because of these reasons, it is mandatory for the producer to manage the waste. As for the management, in article 11 of Regulation of Government no. 101 of 2014 it is explained that the activities include the reducing, storing, collecting, transporting, utilizing, processing and/or stockpiling.

Toxic and hazardous waste materials have characteristics that are different from the waste in general, mainly due to its unstable nature. The stability of hazardous and toxic materials is influenced by external factors such as pressure or friction, temperature and/or mixed with other materials, which may trigger reactive, flammable, explosive, or poisonous feature. Toxic and hazardous wastes generated in industrial activities consist of used batteries, lamps, chemical bottles and oil-contaminated fabrics, oil residues, diesel, chemical waste, chemical liquid residues, tinner and residual combustion processes occurring at coal boilers.

One of the food industry in West Kalimantan which is engaged in instant noodle type of food which every production process results in the waste that can potentially pollute the environment, the waste can be in the form of dangerous and toxic materials, also non-toxic and hazardous materials.

Types of toxic and hazardous wastes produced in the instant noodle food industry are majun, filter oil, paint cans, chemical bottles, contaminated packaging, ex-freon tubes, lamps, toner + TDI, solid and liquid chemical waste, contaminated waste pollen, wet battery and dry accu, polyclinic waste, bottom ash \& fly ash. Toxic and hazardous wastes have toxic and corrosive characteristic according to Regulation of Government No. 101 of 2014 on Waste Management of Hazardous and Toxic Substances.

This research aims to describe the management of toxic and hazardous waste materials in the instant noodle food industry by referring to the applicable procedures and requirements. In the end, hopefully this research will give contribution to development based on low carbon effects where this development philosophy now becomes very important to prevent and reduce climate change.

\section{Method}

The type of research that will be used is qualitative research with descriptive analysis. According to Sugiyono (2014), this method could describe or give an idea of the object beyond research through data or samples which have been collected without doing an analysis and yield conclusions that apply to public. Sampling method in this research is Purposive Sampling with a certain consideration. This particular consideration, for example, the sample (person) who is considered knows best about what to expect, or maybe he as the leader so that it will allow researchers to explore the object to be studied (Sugiyono, 2011).

As for the sample in this study is the source of waste, waste generating units and temporary storage of toxic and hazardous waste materials. While Respondents in this study are Environmental Manager or authorized officer in the management of toxic and hazardous materials waste and coordinator or officer of waste generating units of hazardous and toxic materials. The technique used in this research data collection is by direct observation at the source of waste generator, temporary shelter, third party related to the system of a permit, collection, transportation of waste and interview to resource person of toxic and hazardous waste management as the informant.

\section{Result and Discussion}

\subsection{Overview of the Instant Noodle Food Industry}

One food industry located in West Kalimantan is engaged in the instant noodle type of food and other types of noodle food. The nearest distance of the activity location with the capital of the district is $6 \mathrm{~km}, 56 \mathrm{~km}$ from the district capital, $9 \mathrm{~km}$ from the provincial capital, $0.5 \mathrm{~km}$ from the residential area, and public 
facilities such as; hospital $13 \mathrm{~km}$, school $1 \mathrm{~km}$, market 7 $\mathrm{km}$, and places of worship such as mosque or surau 1 $\mathrm{km}$.

The installed production capacity based on the expansion license from the State Minister / Head of Capital Investment and Development Agency No.207 / I / IP / PMDN / 2014 is 629,032,000 pcs / year with main raw materials of wheat flour and additional raw materials such as cooking oil, spices, salt, and water as well as auxiliary raw materials such as etiquette, cardboard, foam cup, and fork.

In the production process of instant noodles made by the food industry solid waste was produced, such as noodles with a failed wave, broken noodles and the rest of the failed etiquette and cardboard packaging. Another solid waste produced outside the production process of instant noodle industry are the organic waste, paper, wood, cloth, rubber, plastic wrap, metal, and glass. Those solid wastes are brought to a temporary shelter and some are immediately sold to the container. The industrial production process that produces the most waste of hazardous and toxic materials is the combustion process that occurs in coal boilers and produces bottom ash \& fly ash. The resulting toxic and hazardous waste materials are then collected and rafted and placed on top of the pallet. The waste is then placed where the temporary shelter that has been provided for later submitted to the toxic and hazardous waste container with legal permission from the Ministry of Environment and Forestry of the Indonesian Republic.

\subsection{Identification of Toxic and Hazardous Waste}

The process of identifying toxic and hazardous waste materials is to determine the source of toxic and hazardous waste materials and is the first important step in waste management system to determine whether the waste produced meets the definition of hazardous and toxic, as it is to determine how waste should be managed. The waste generator has the responsibility to determine whether the waste falls into the category of toxic and hazardous waste.

Table 1. Identification of toxic and hazardous waste materials

\begin{tabular}{|c|l|c|c|}
\hline No & \multicolumn{1}{|c|}{ Waste type } & Characteristic & Waste Code \\
\hline 1 & Majun & $\begin{array}{c}\text { Flammable } \\
\text { solids }\end{array}$ & B110d \\
\hline 2 & Filter oil & Toxic & B340-1 \\
\hline 3 & $\begin{array}{l}\text { Spray Can, } \\
\text { Chemical bottle, } \\
\text { Contaminated } \\
\text { Packaging }\end{array}$ & Toxic & B104d \\
\hline 4 & Ex Freon Tube & Toxic & B104d \\
\hline 5 & Lamp & Toxic & B107d \\
\hline 6 & Toner + TDI & Toxic & B339-2 \\
\hline 7 & Chemical Waste & Toxic & A106d \\
\hline 8 & Oli + Used Fuel & $\begin{array}{c}\text { Flammable } \\
\text { Liquids }\end{array}$ & B105d \\
\hline 9 & $\begin{array}{l}\text { Sawdust } \\
\text { Waste }\end{array}$ & $\begin{array}{c}\text { Flammable } \\
\text { solids }\end{array}$ & B110d \\
\hline
\end{tabular}

\begin{tabular}{|c|l|c|c|}
\hline & Contamination & & \\
\hline 10 & $\begin{array}{l}\text { Wet and Dry } \\
\text { Battery }\end{array}$ & Corrosive & A102d \\
\hline 11 & Polyclinic Waste & Toxic & B337-1 \\
\hline 12 & Fly Ash & Toxic & B409 \\
\hline 13 & Bottom Ash & Toxic & B410 \\
\hline
\end{tabular}

\subsection{Toxic and Hazardous Waste Reduction}

Reduction of toxic and hazardous waste materials is the activity of the producer to reduce the amount and / or the characteristic of toxic and hazardous waste before it is discharged from a business and or activity by optimizing raw materials in the process of house keeping, substance substitution, process modification, usage of environmentally friendly technologies and other reduction efforts. Minimization of toxic and hazardous waste materials is intended to ensure that the B3 waste generated in each production is as low as possible, or even zero.

In this case, one of the food industries engaged in the field of instant noodle type of food has substituted the use of coal fuel with palm shells. For now, the fuel for the boiler is still a mixture of coal and palm shells with a percentage of $20 \%$ shell of palm and $80 \%$ of coal. It is expected that in the future the food industry will continue to achieve the goal of using $0 \%$ coal and $100 \%$ palm shell.

\subsection{Storage of Toxic and hazardous waste Materials}

Storing is the activity of temporarily placing toxic and hazardous wastes in warehouses for the purpose of temporarily storing waste materials before handing it over to collectors and carriers, in accordance with applicable procedures and regulations, including the provision of symbols and labels of hazardous waste materials and toxic with reference to Regulation of Government no. 101 of 2014 on Management of Hazardous and Toxic Materials.

Storing the toxic and hazardous wastes shall be accompanied by a toxic and hazardous waste management permit for storage activities. Storage of toxic and hazardous wastes must be above ground level and is prohibited to be underground. This instant noodle food industry has been storing waste in accordance with the prevailing regulations, proven by a temporary shelter warehouse which is safe from rain and flood water, equipped with a good spatial plan, emergency equipment system, fully permitted waste material storage, equipped with a $\log$ book and the scale of toxic and hazardous waste materials.

In the storage of toxic and hazardous waste materials, the company is responsible for recording waste, preparing the waste balance and reporting the balance of toxic and hazardous waste materials every 3 (three) months to the State Ministry of Environment, Provincial Environmental Agency and the Office of the Environment of Mempawah District. 
Toxic and hazardous waste is stored up to 180 days in the temporary storage, this is done the amount of waste produced is less than $50 \mathrm{~kg}$ per day. While for coal waste; bottom ash \& fly ash, stored for maximum 90 days because the amount of waste produced more than $50 \mathrm{~kg}$ per day. However, due to limited transportation by third parties which are only twice a year, toxic and hazardous waste producers apply for a license to extend the retention period to the Regent of Mempawah District and related offices.

In the storage of toxic and hazardous waste materials, packaging and symbols and labels are placed on waste packaging to provide an identity in order to simplify the identification. The marks help to give basic information about the type and characteristics or nature of toxic and hazardous waste materials for people who carry out waste management and for waste treatment supervisors. The marking of toxic and hazardous wastes is carried out by the food industry complies with the requirements contained in Regulation of Government No. 101 of 2014 on the management of toxic and hazardous waste.

Table 2. Storage Duration of Hazardous and Toxic Materials

\begin{tabular}{|c|l|c|c|}
\hline No & Type of Waste & $\begin{array}{c}\text { Amount of } \\
\text { Waste Per Day }\end{array}$ & $\begin{array}{c}\text { Storage } \\
\text { Duration }\end{array}$ \\
\hline 1 & Majun & $<50 \mathrm{Kg}$ & 365 Day \\
\hline 2 & Filter oli & $<50 \mathrm{Kg}$ & 365 Day \\
\hline 3 & $\begin{array}{l}\text { Spray Can, } \\
\text { Chemical bottle, } \\
\text { Contaminated } \\
\text { Packaging }\end{array}$ & $<50 \mathrm{Kg}$ & 365 Day \\
\hline 4 & Ex Freon Tube & $<50 \mathrm{Kg}$ & 365 Day \\
\hline 5 & Lamp & $<50 \mathrm{Kg}$ & 365 Day \\
\hline 6 & Toner + TDI & $<50 \mathrm{Kg}$ & 365 Day \\
\hline 7 & Chemical Waste & $<50 \mathrm{Kg}$ & 180 Day \\
\hline 8 & Oil+ Used Fuel & $<50 \mathrm{Kg}$ & 365 Day \\
\hline 9 & $\begin{array}{l}\text { Sawdust } \\
\text { Waste } \\
\text { Contamination }\end{array}$ & $<50 \mathrm{Kg}$ & 365 Day \\
\hline 10 & $\begin{array}{l}\text { Wet and Dry } \\
\text { Battery }\end{array}$ & $<50 \mathrm{Kg}$ & 180 Day \\
\hline 11 & Polyclinic Waste & $<50 \mathrm{Kg}$ & 365 Day \\
\hline 12 & Fly Ash & $>50 \mathrm{Kg}$ & 90 Day \\
\hline 13 & Bottom Ash & $>50 \mathrm{Kg}$ & 90 Day \\
\hline
\end{tabular}

\subsection{Accumulation of Toxic and Hazardous Waste}

Accumulation is the activity of collecting toxic and hazardous waste by third parties from waste generators like the food industry for the purpose of collecting temporary toxic and hazardous wastes in a warehouse before handing it over to processors or beneficiaries or landfills in accordance with applicable procedures and regulations.

The temporary collection of toxic and hazardous waste by the food industry has been qualified by having a license and a temporary collection warehouse that meet with the requirement. It has good spatial plan, emergency system equipment, safe from rain and flood.

\subsection{Transportation of Toxic and hazardous waste Materials}

Transporting is the activity of removing toxic and hazardous waste by the third party from the warehouse to the processor or utilizer or hoarder in accordance with applicable procedures and regulations.

Waste generator, in the case of toxic and hazardous waste material transport, is cooperated with PT. Indostar Cargo which is located at Jalan Letda Sujono no. 72, Medan. The waste is later sent to the shelter and processing of hazardous and toxic materials; PT. Prasadha Pamunah Industrial Waste in Cileungsi, Bogor. While for the bottom ash \& fly ash are sent to the cement factory as a mixture of cement making.

PT. Indostar Cargo as a third party acting as a transporter of toxic and hazardous wastes generated by waste producers has recommendations from the Ministry of Environment and transportation licenses from the Ministry of Transportation.

Obstacles experienced by the food industry in transport are the unavailability of transporters and users in West Kalimantan. The waste can only be transported twice in one year by a third party.

\subsection{Utilization, Processing, and Piling of Toxic and Hazardous Waste}

Utilization is a reuse, recycling and/or recovery activity that aims to convert toxic and hazardous waste into the usable products as substitutes for raw materials, auxiliaries, and/or fuels which are safe for human health and the environment.

This instant noodle food industry does not take advantage of the toxic and hazardous waste materials they produce, but hand over the utilization of such waste to third parties who already have a license from the Ministry of Environment to exploit toxic and hazardous waste.

The constraints the food industry is facing about exploiting toxic and hazardous wastes are limited human resources and employee competencies in the management wastes, the costly utilization licenses, and the provision of equipment and sites for waste utilization and treatment which are quite burdensome.

\section{Conclusion}

Types of toxic and hazardous wastes produced by this instant noodle food industry are majun, oil filters, paint cans, chemical bottles, contaminated packaging (oil jug), ex freon tubes, lamps, toners + TDI, solid and liquid chemical waste , used oil + diesel, waste polluted sawdust, dry and wet battery, polyclinic waste, bottom ash \& fly ash. Most of the waste produced are bottom ash \& fly ash of 557,300 tons (July 2016 - June 2017) which is a source of potential contamination for the environment around the company. 
The executing officer or the authorized officer responsible for the management of toxic and hazardous wastes is only 1 (one) person, assisted by 1 (one) cleaning service special for waste. The facilities and infrastructure supporting the management of toxic and hazardous waste materials comprise of storage warehouse for toxic and hazardous wastes materials, safety boxes, personal protective equipment for waste management personnel, special waste bins for toxic and hazardous waste and fire extinguishers at the temporary shelter.

Based on observations of the management of toxic and hazardous waste in the food industry, this type of instant noodle has met the requirements in the Regulation of Government No. 101 of 2014 on the Management of Toxic and hazardous waste. Thus, waste management have been fulfilling low carbon development. As we know that almost all waste produced by industry may yield carbon. Along wiith the increase of industrial waste may cause the carbon amount in atmosphere increases too. These have positive correlation. That's why carbon must be reduced with good management in waste, especially toxic and hazardous waste.

\section{References}

1. Chuang, K.-H., Lu, C.-H., Chen, J.-C., \& Wey, M.Y. (2018). Reuse of bottom ash and fly ash from mechanical-bed and fluidized-bed municipal incinerators in manufacturing lightweight aggregates .pdf. Ceramics International Journal. https://doi.org/https://doi.org/10.1016/j.ceramint.201 8.04 .070

2. Darlington, R., Staikos, T., \& Rahimifard, S. (2009). Analytical methods for waste minimisation in the convenience food industry. Waste Management, 29(4), 1274-1281. https://doi.org/10.1016/j.wasman .2008 .08 .027

3. Das, A., Gupta, A. K., \& Mazumder, T. N. (2012). Vulnerability assessment using hazard potency for regions generating industrial hazardous waste. Journal of Hazardous Materials, 209-210, 308-317. https://doi.org/10.1016/j.jhazmat. 2012.01.025

4. Fauziah Anggraini, Mursid Rahardjo, O. S., \& Bagian. (2015). Sistem Pengelolaan Limbah B3 Terhadap Indeks Proper di RSPI Prof. Dr. Sulianti Saroso. Jurnal Kesehatan Masyarakat, 3(3).

5. Gidarakos, E., \& Aivalioti, M. (2012). Industrial and hazardous waste management. Journal of Hazardous Materials, 207-208, 1-2. https://doi.org/ 10. 016/j. jhazmat.2011.10.083

6. Heidrich, O., Harvey, J., \& Tollin, N. (2009). Stakeholder analysis for industrial waste management systems. Waste Management, 29(2), 965-973. https://doi.org/10.1016/j.wasman.2008.04. 013

7. Hodul, J., Dohnálková, B., \& Drochytka, R. (2015). Solidification of hazardous waste with the aim of material utilization of solidification products. Procedia Engineering, 108, 639-646. https://doi.org /10.1016/j.proeng.2015.06.193
8. Lampiran Peraturan Pemerintah RI No. 101 Tahun 2014 Tentang Pengelolaan Limbah Bahan Berbahaya Dan Beracun (2014).

9. Naganathan, S., Mohamed, A. Y. O., \& Mustapha, K. N. (2015). Performance of bricks made using bottom ash \& fly ash. Construction and Building Materials, 96, 576-580. https://doi.org/10.1016/j. conbuildmat.2015.08.068

10. Peraturan Menteri LH RI No 14 Tahun 2013 Tentang Simbol Dan Label Limbah Bahan Berbahaya Dan Beracun (2013).

11. Peraturan Menteri LHK RI No. P.55/MenlhkSetjen/2015 Tentang Tata Cara Uji Karakteristik Limbah Bahan Berbahaya Dan Beracun (2015).

12. Peraturan Menteri Negara LH No. 02 Tahun 2008 Tentang Pemanfaatan Limbah Bahan Berbahaya Dan Beracun (2008)

13. Peraturan Menteri Negara LH No 30 Tahun 2009 Tentang Tata Laksana Perizinan Dan Pengawasan Pengelolaan Limbah Bahan Berbahaya Dan Beracun Serta Pengawasan Pemulihan Akibat Pencemaran Limbah Bahan Berbahaya Dan Beracun Oleh Pemerintah Daerah (2009).

14. Peraturan Pemerintah Republik Indonesia No. 101 Tahun 2014 Tentang Pengelolaan Limbah Bahan Berbahaya Dan Beracun (2014).

15. Priono, N. J. (2018a). Limbah B3: Pengelolaan Limbah B3 Sesuai PP 101 tahun 2014. Retrieved from https://sadkes.net/2018/04/01/limbah-b3/

16. Priono, N. J. (2018b). Simbol Limbah B3 \& Label Limbah B3. Retrieved from https://sadkes.net/ 2018/03/31/contoh-simbol-limbah -b3-label-limbahb3/

17. Rafieizonooz, M., Mirza, J., Salim, M. R., Hussin, M. W., \& Khankhaje, E. (2016). Investigation of coal bottom ash and fly ash in concrete as replacement for sand and cement. Construction and Building Materials, 116, 15-24. https://doi.org/10. 1016/j.conbuildmat.2016.04.080

18. Sulistyani, D. (2007). Pengelolaan Limbah Bahan Berbahaya Dan Beracun. Buletin LIMBAH, 11.

19. Undang-Undang Republik Indonesia Nomor 32 Tahun 2009 Tentang Perlindungan Dan Pengelolaan Lingkungan Hidup (2009).

20. Vu, D. H., Wang, K. S., Chen, J. H., Nam, B. X., \& Bac, B. H. (2012). Glass-ceramic from mixtures of bottom ash and fly ash. Waste Management, 32(12), 2306-2314. https://doi.org/10.1016/j.wasman.2012. 05.040

21. Wahyudianto, F. E., \& Boedisantoso, R. (2016). Penerapan PROPER sebagai Alat Pemicu Inovasi Teknologi Industri Berkelanjutan, (Cinia), 59-64.

22. Yilmaz, O., Kara, B. Y., \& Yetis, U. (2017). Hazardous waste management system design under population and environmental impact considerations. Journal of Environmental Management, 203, 720-731. https://doi.org/10. 1016/j.jenvman.2016.06.015. 